\title{
Effect of Alpha-lipoic Acid on the Metabolism of Arsenic in Arsenic-loaded Isolated Liver Tissues of Rat
}

\author{
Noor-E-Tabassum
}

\begin{abstract}
:
The patient of chronic arsenic toxicity shows oxidative stress. To overcome the oxidative stress, several antioxidants such as $\beta$-carotene, ascorbic acid, $\alpha$-tocopherol, zinc and selenium had been suggested. In the present study, universal antioxidant (both water and lipid soluble antioxidant) alpha-lipoic acid was used to examine the effectiveness of this thiot on arsenic metabolism. Alpha-lipoic acid increases the methylation of inorganic arsenic and releases monomethylarsenic acid (MMA) and dimethylarsenic acid (DMA) from the intracellular pool. These results suggest that alpha-lipoic acid increases metabolism of arsenic thereby reduces the concentration of arsenic from arsenic-loaded isolated liver tissues of rat.
\end{abstract}

\section{Introduction:}

Toxic effects arising from arsenic contamination of ground water is an emerging public health problem in Bangladesh. It is estimated that at least 61 districts out of 64 districts of Bangladesh have been affected with arsenic contamination in ground water and about 37-77 million of the total population of 125 million of Bangladesh are at risk of drinking contaminated water with arsenic concentrations elevated above world health organization's standard $50 \mu \mathrm{g} / \mathrm{L}$ '. Arsenic must be considered an important environmental toxicant because of its acute and chronic toxic properties and extensive distribution in the nature ${ }^{2}$.

Trivalent inorganic arsenic exerts its toxic effects through several mechanisms; the most important significant mechanism is reversible

Assistant Professor, Department of Pharmacology \& Therapeutics. Medical College for Women \& Hospital, Dhaka. combination with sulfhydryl groups (-SH). Trivalent inorganic arsenic binds to and inactivates intracellular $-\mathrm{SH}$ containing compounds, especially lipoic acid and $\alpha$-keto oxidases, thereby disrupting cellular metabolism and inhibiting enzyme systems essential for oxidative phosphorylation ${ }^{3}$. Evidence of many studies suggests that toxicity of arsenic not only due to its high affinity to $-\mathrm{SH}$ but also through generation of free radicals during arsenic metabolism in cells ${ }^{4}$. The metabolism of inorganic arsenic in humans involves two processes, the reaction of reduction that converts pentavalent arsenicals to trivalent. Inorganic arsenic is methylated to monomethylarsenic acid (MMA) and dimethylarsenic acid (DMA) in the body and are considered end product of arsenic metabolism. The first methylation reaction is rate limiting, can be stimulated by glutathione and which causes reduction of arsenate to arsenite ${ }^{2,5,6}$. Recent in vitro work 
on arsenic metabolism has shown that glutathione was necessary for full activity of arsenic methylation?. The second step reduction of oxidative methylation, which occurs mainly in the liver cytosol requires Sadenosylmethionine (SAM) and possibly other methyl donors (choline, cysteine, glutathione, reduced lipoic acid) to produce MMA and DMA. The methylation process is dosedependent and as dose of arsenic increases, a reduction of the percentage of DMA is observed in urine while retention of arsenic is higher".

Glutathione and glutathione related enzymes stimulate the arsenic detoxification process by modulating arsenic speciation?. Buchet and Lauwerys in their study state that a depletion of liver glutathione exceeding $90 \%$ of the control value leads to decreased urinary level of MMA, DMA and increased level of inorganic arsenic ${ }^{8}$. The metabolism and excretion of these heavy metals depend on the presence of antioxidants and thiols that aid arsenic methylation ${ }^{10}$. Glutathione, lipoic acid, selenium, alpha-tocopherol and ascorbic acid have specific role in mobilization and excretion of arsenic ${ }^{6.11}$.

Human body also contains alpha-lipoic acid which is a short chain fatty acid with - SH that has potent antioxidant property (both water and lipid soluble antioxidant $)^{12}$. Alpha-lipoic acid is a disulfide compound that is found naturally in mitochondria as the coenzyme for pyruvate dehydrogenase and $\propto$-ketglutarate dehydrogenase for several redox reactions. Exogenously supplied alpha-lipoic acid is readily taken up by a variety of cells and tissues in which it is rapidly reduced by $\mathrm{NADH}$ or NADPH-dependent enzymes to dihydrolipoate (DHLA). They both have varied properties including quenching of reactive oxygen and nitrogen species (hydroxyl radicals, superoxide, hypochlorous acid, and peroxinitrite) and metal-chelation $\left(\mathrm{Cd}^{2+}, \mathrm{Fc}^{3+}, \mathrm{Cu}^{2+}, \mathrm{Zn}^{2+}\right)^{13}$. Exogenous administration of alpha-lipoic acid has been found to be effective in many pathological conditions associated with oxidative stress, diabetic neuropathy, metal toxicity, hypertension, diabetic complications and cataracts $^{1.4}$. A number of in vitro studies also proved its antioxidant potency. Alpha-lipoic acid also causes an increase in intracellular GSH in vitro as well as in vivo. Cysteine is important precursor for glutathione synthesis. Alpha-lipoic acid has the ability to serve as a continuous supplier of cysteine ${ }^{15}$. Therefore, the purpose of this study was to cvaluate the effect of alpha-lipoic acid on the arsenic methylation in the arsenic-loaded isolated liver tissue of rat.

\section{Materials and method:}

Chemicals and reagents: Arsenic trioxide $\left(\mathrm{As}_{2} \mathrm{O}_{3}\right)$, MMA and DMA were purchased from Sigma Chemical Company (St. Louis, MO, USA). Chemicals and reagents to measure total protein were from Human Gmbh (Germany). Ion-exchange column chromatography (AG 50W-X 8) was purchased from Bio-Rad Laboratory. Alphalipoic acid was a gift from Opsonin Pharma Limited, Bangladesh.

Preparation of isolated liver tissues: The study was carried out on isolated liver tissues of Long Evans Norwegian adult healthy male rats weighing about $150-180 \mathrm{gm}$. The rats were housed in standard plastic cages in a clean rodent room where a 12-hour light/dark cycle was maintained. On the day of experiment, rats were sacrificed under 
chloroform anesthesia and the abdomen was opened by giving a midline incision. The liver was dissected out and immersed immediately into the physiological solution placed in ice bath. The liver tissues were chopped into small pieces (approximately $2 \mathrm{~mm}$ in size).

Research design (Fig.-1): Several test tubes were taken and marked as three groups: Group I-Control; Group II-Arsenic $(50 \mu \mathrm{g})$; Group III-Arsenic $(50 \mu \mathrm{g})+$ alpha-lipoic acid $(15$ $\mu \mathrm{M}$ ). Number of the test tubes (samples) in each group was six and each test tube contained $250 \mathrm{mg}$ small pieces of liver tissues immersed in $5 \mathrm{ml}$ of physiological solution. Isolated liver tissues of rat were incubated with in presence or absence of arsenic $(50 \mu \mathrm{g})$ at $37^{\circ} \mathrm{C}$ for 45 minutes. After the first incubation, tissues were washed twice with physiological solution. The purpose of this incubation was to load the liver tissues with arsenic. Then during the second incubation (at $37^{\circ} \mathrm{C}$ for another 45 minute), liver tissues were treated with or without alpha-lipoic acid (15 $\mu \mathrm{M})$. At the end of second incubation, speciation of arsenic was done both in supernatant (medium) and in tissues (after extraction by $50 \%$ methanol).

Isolated liver tissues

Incubated for 45 minutes with or without presence of arsenic

After the end of incubation period, tissues were washed and again

incubated for 45 minutes at $37^{\circ} \mathrm{C}$ with or without presence of alpha-lipoic acid

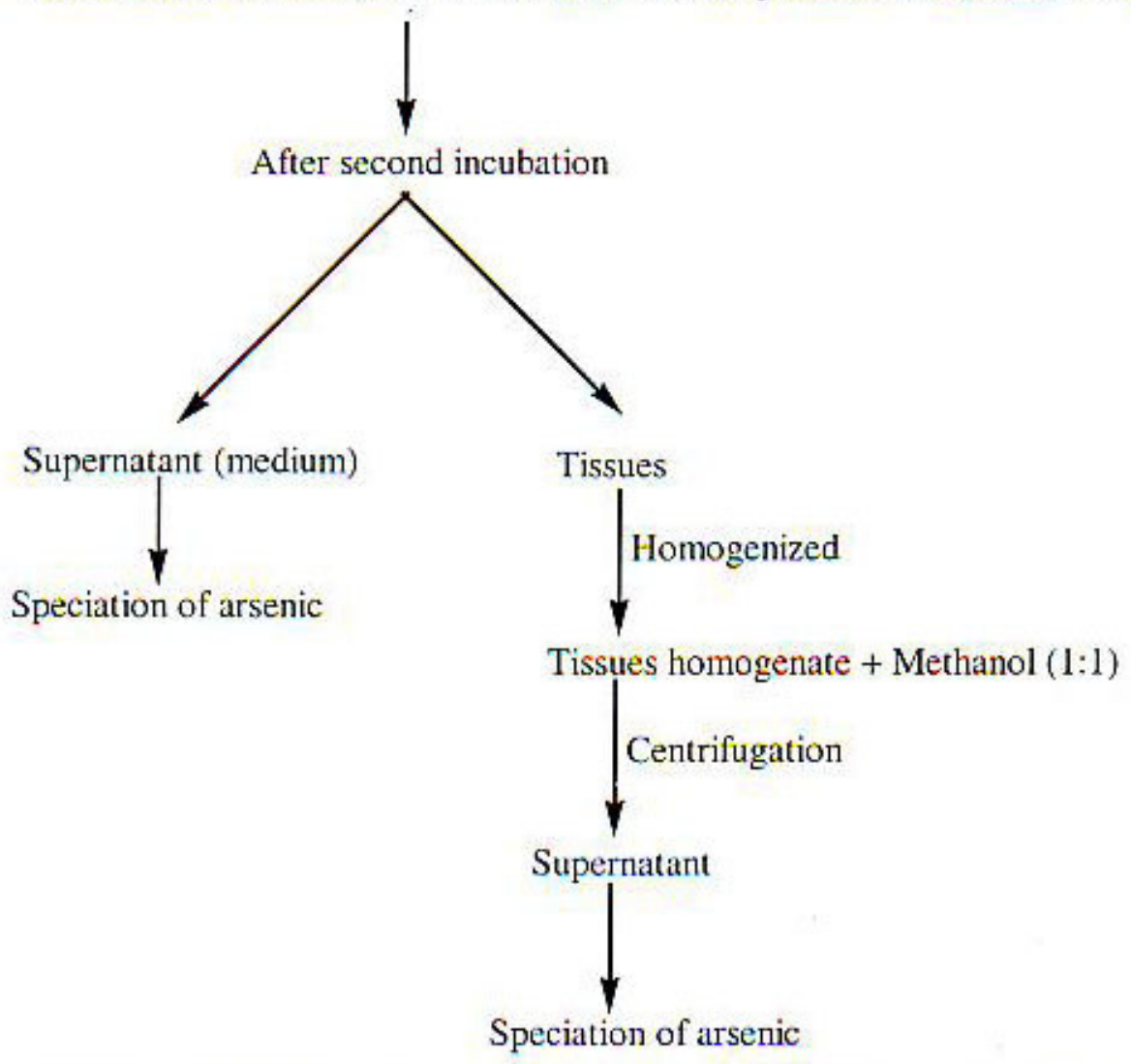

Figure-1: Diagram showing the processing of samples for chemical analysis. 
Tissue supernatant / medium Applied to the top of the column Pass through cation exchange resin (AG 50W-X 8)

Then pass $15 \mathrm{ml} 0.5 \mathrm{M} \mathrm{HCl}$

Collection of $15 \mathrm{ml}$ eluant (inorganic arsenic)

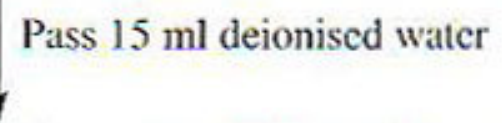

Collection of $15 \mathrm{ml}$ eluant (monomethylarsenic acid)

Collection of $30 \mathrm{ml}$ eluant (dimethylarsenic acid)

At the end of the procedure, ion-exchange column chromatography washes with $4 \mathrm{M} \mathrm{HCl}$.

Figure -2: Flow chart showing the procedure of speciation of arsenic

Speciation of arsenic (Fig.-2): To evaluate the effect of alpha-lipoic acid on arsenic metabolism, the supernatant after second incubation or the methanol $(50 \%)$ extract of tissue homogenate was passed through the ion-exchange column chromatography (AG $50 \mathrm{~W}-\mathrm{X} 8$ ) to separate the arsenic metabolites according to the method of Tam et $\mathrm{al}^{16}$. According to this method inorganic arsenic, MMA and DMA were sequentially eluted with $15 \mathrm{ml}$ of $0.5 \mathrm{M} \mathrm{HCl}, 15 \mathrm{ml}$ of deionized water and $30 \mathrm{ml}$ of $4 \mathrm{~N} \mathrm{NH}_{4} \mathrm{OH}$. The different metabolites (both in supernatant and in methanol extract) were analyzed by using Atomic Absorption Spectro-photometer with Hydride Generator (AAS-HG). The methanol extraction was carried out under dimmed light.
Protein assay: Protein concentration of tissues was estimated by 'Biuret' method described by Weichselbaum ${ }^{17}$, using bovine serum albumin $(8 \mathrm{gm} / \mathrm{dl})$ as standard.

Statistical analysis: Statistical analyses were carried out using Statistical Package for Social Science (SPSS), version 9.0, USA. The values were expressed as mean \pm SEM for results obtained with six samples in each group and the data of arsenic speciation were subjected to statistical analysis using unpaired t-test. Statistical significance was determined by $p$ value less than 0.05 . 


\section{Results:}

Table-I shows the effect of alpha-lipoic acid on arsenic metabolism. The amounts of inorganic arsenic, MMA and DMA in the supernatant of only arsenic-treated liver tissues (G-I) after second incubation were $13.66 \pm 0.90,17.38 \pm 0.72$ and $27.00 \pm 1.46$ $\mu \mathrm{g} / \mathrm{gm}$ protein respectively. But when the arsenic-loaded liver tissues were incubated with alpha-lipoic acid at a concentration of 15 $\mu \mathrm{M}$ (G-II), the amount of inorganic arsenic, MMA and DMA (in supernatant) increased to inorganic arsenic, MMA and DMA in, tissues were $59.09 \pm 1.18 \mu \mathrm{g} / \mathrm{gm}, 23.78 \pm 1.57$ and $9.91 \pm 0.86 \mu \mathrm{g} / \mathrm{gm}$ protein respectively. When the arsenic-loaded tissues were treated with alpha-lipoic acid, the amount of total arsenic in tissues was decreased to $42.8 \mu \mathrm{g} / \mathrm{gm}$ protein (G-II) and in which inorganic arsenic, MMA and DMA was present at a concentration of $26.29 \pm 0.76 \mu \mathrm{g} / \mathrm{gm}, 11.83 \pm 0.57 \mu \mathrm{g} / \mathrm{gm}$ and $4.68 \pm 0.27 \mu \mathrm{g} / \mathrm{gm}$ protein respectively and they were statistically significant $(p<0.001)$ as compared to only arsenic-treated group.

Table-I: Effect of alpha-lipoic acid on the metabolism of arsenic in arsenic-loaded isolated liver tissues of rat

\begin{tabular}{|c|c|c|c|c|c|c|}
\hline \multirow{2}{*}{ Group } & \multicolumn{2}{|c|}{$\begin{array}{c}\text { Amount of arsenic metabolites in supernatant } \\
\text { after second incubation }(\mu \mathrm{g} / \mathrm{gm} \text { protein) }\end{array}$} & \multicolumn{2}{c|}{$\begin{array}{c}\text { Amount of arsenic metabolites within tissues } \\
\text { after second incubation }(\mu \mathrm{g} / \mathrm{gm} \text { protein) }\end{array}$} \\
\cline { 2 - 7 } & $\begin{array}{c}\text { Inorganic } \\
\text { arsenic }\end{array}$ & MMA & DMA & $\begin{array}{c}\text { Inorganic } \\
\text { arsenic }\end{array}$ & MMA & DMA \\
\hline I & Nd & Nd & Nd & Nd & Nd & Nd \\
\hline II & $13.66 \pm 0.90$ & $17.38 \pm 0.72$ & $27.00 \pm 1.46$ & $59.09 \pm 1.18$ & $23.78 \pm 1.57$ & $9.91 \pm 0.86$ \\
\hline III & $22.08 \pm 0.84^{\circ}$ & $32.82 \pm 1.80^{\circ}$ & $55.28 \pm 0.64^{*}$ & $26.29 \pm 0.76^{\circ}$ & $11.83 \pm 0.57^{\circ}$ & $4.68 \pm 0.27^{\circ}$ \\
\hline
\end{tabular}

Group I-Control tissues treated with only physiological solution: Group 11-Tissues were treated with arsenic (50 $\mu \mathrm{g})$ in first incubation and physiological solution in second incubation; Group III. Tissues were treated with arsenic (50 $\mathrm{\mu g})$ in first incubation and alpha-lipoic acid $(15 \mu \mathrm{M})$ in second incuhation; Nd means not detectable: Valucs were expressed as mean $=$ SEM of six samples in each group: " $p<0.001$, when compared with only arsenic-treated group; Inorganic arsenic. MMA and DMA were extracted from tissues by extraction with $50 \%$ methanol.

$22.08 \pm 0.84 \mu \mathrm{g} / \mathrm{gm}, 32.82 \pm 1.80$ and $55.28 \pm$ $0.64 \mu \mathrm{g} / \mathrm{gm}$ protein respectively which was statistically significant $\quad(p<0.001) \quad$ in comparison to arsenic-treated group. That is, alpha-lipoic acid increases the metabolism of inorganic arsenic to MMA and DMA.

Table-I also shows the concentration of arsenic metabolites that was retained within the tissues, treated with or without alphalipoic acid $(15 \mu \mathrm{M})$ and which were extracted from tissues by methanol ( $50 \%)$. After second incubation the amount of total arsenic in only arsenic-treated tissues was $92.78 \mu \mathrm{g} / \mathrm{gm}$ protein (G-1), in which the amount of

\section{Discussion:}

The present study shows that incubation of liver tissues with trivalent arsenic accumulates arsenic within the liver tissues and metabolizes to MMA and DMA, which were then released into the medium (supernatant). In the course of incubation with arsenic trioxide in alpha-lipoic acid treatment group, the MMA and DMA were significantly increased $(p<0.001)$ in comparison to only arsenic-treated group. This means that alphalipoic acid increases metabolism of arsenic in the isolated liver tissues into its methylated 
forms. This may be due to elevating the level of GSH by alpha-lipoic acid. GSH has been suggested to be a necessary component for arsenic metabolism probably in the initial reduction of arsenate to arsenite and in subsequent oxidative methylation ${ }^{7,8}$. When GSH levels were reduced within the cells, MMA and DMA were decreased and hepatic arsenic level was increased ${ }^{18}$. Furthermore, a decrease in the levels of arsenic metabolites in supernatant in only arsenic-treated group might indicate that the methylation step was inhibited by inorganic arsenic in the tissues. Shila et al suggested that alpha-lipoic acid may modulate the methylation of arsenic ${ }^{19}$. It may be due to influence of alpha-lipoic acid on metabolism of arsenic in the isolated liver tissues of rat, there may be less free inorganic arsenic available in tissues for methylation and only a small amount of metabolites remains within the tissues. It is likely that interactions of trivalent arsenic metabolites with proteins and other cellular constituents are responsible for retention and toxic effects of arsenic in tissues of animals and humans exposed to arsenic ${ }^{20}$. However, Styblo et al suggested that MMA and DMA derivatives were at least as cytotoxic as inorganic arsenic in most cell types and associated with a variety of adverse effects including inhibition of several enzyme, damage of DNA structure and activation of gene transcription ${ }^{21}$. This study also shows that treatment of liver tissues with alpha-lipoic acid significantly $(p<0.001)$ decreases the amount of MMA and DMA within tissues. As has been suggested, GSH could serve as the source of electrons in a sulphide-disulphide couple to drive the arsenate to arsenite reduction, as well as possibly to mediate reduction of arsenic in its various other pentavalent states including the methylated metabolites ${ }^{18}$. GSH also plays an important role in detoxification of arsenic by stimulation of excretion of methylated arsenic compounds ${ }^{6,8,9}$.

In conclusion, the finding of the present study suggests that alpha-lipoic acid increases metabolism of arsenic in tissues. This may be due to elevating the level of GSH by alphalipoic acid thereby increases the level of MMA and DMA in supernatant, while decreases the levels of metabolites in tissues. However, further studies with alpha-lipoic acid need to be carried out in vivo to ascertain their therapeutic efficacy in modifying arsenic methylation in human.

\section{References:}

1. Frisbie SH, Mitchell EJ, Yusuf AZ, et al. The development and use of an innovative laboratory method for measuring arsenic in drinking water from Western Bangladesh. Environ Health Perspect 2005; 113: 1196-04.

2. Abernathy CO, Thomas DJ, Calderon RL. Health effects and risk assessment of arsenic. J Nutr 2003; 133: 1536-38.

3. Miller WH, Schipper HM, Lee JS, et al. Mechanisms of action of arsenic trioxide. Cancer Res 2002; 62: 3893-03.

4. Shi H, Shi X, Liu J. Oxidative mechanism of arsenic toxicity and carcinogenesis. Molecul Cell Biochem 2004; 255: 67-78.

5. Vahter M. Biotransformation of trivalent and pentavalent inorganic arsenic in mice and rats. Environ Res 1981; 25: 286-93.

6. Patrick L. Toxic metals and antioxidants: Part II. The role of antioxidants in arsenic and cadmium toxicity. Alt Med Rev 2003; 8: 106-28. 
7. Buchet JP, Lauwerys R. Role of thiols in vitro methylation of inorganic arsenic by rat liver cytosol. Biochem Pharmacol 1988; 37: 3149-53.

8. Buchet JP, Lauwerys R. Study of factors influencing the in vivo methylation of inorganic arsenic in rats. Toxicol Appl Pharmacol 1987; 91: 65-74.

9. Scott N, Hatlelid KM, MacKenzic NE, Dean CE. Reactions of arsenic(III) and arsenic(V) species with glutathione. Chem Res Toxicol 1993; 6: 102-06.

10. Patrick L. Mercury toxicity and antioxidants: Part I: Role of glutathione and alpha-lipoic acid in the treatment of mercury toxicity. Alt Med Rev 2002; 7 : 456-71.

11. Gregus Z, Stein AF, Varga F, et al. Effect of lipoic acid on billiary excreation of glutathione and metals. Toxicol Appl Pharmacol 1992; 114: 88-96.

12. Kagan VE, Shvedova A, Serbinova E, et al. Dihydrolipoic acid: A universal antioxidant both in the membrane and in the aqueous phase. Reduction of peroxyl, ascorbyl and chromanoxyl radicals. Biochem Pharmacol 1992; 44: 1637-49.

13. Packer L, Witt EH, Tritschler HJ, Alpha lipoic acid as a biological antioxidant. Free Rad Bio Med 1995; 19: 227-50.

14. Smith AR, Shenvi SV, Widlansky M, et al. Lipoic acid as a potential therapy for chronic disease associated with oxidative stress. Curr Med Chem 2004; 11: 1135-46.
15. Busse E, Zimmer G, Schopohl B, et al. Influence of alpha-lipoic acid on intracellular glutathione in vitro and in vivo, Arzneim-Forsch 1992; 42: 829-31.

16. Tam KH, Charbonneau SM, Bryce F, et al. Separation of arsenic metabolites in dog plasma and urine following intravenous injection of As. Anal Biochem 1978; 86: 505-11.

17. Weichselbaum TE. Estimation of serum total protein by Biuret method. Am J Cli Path 1946; 16: 40-48.

18. Vahter M, Marafante E, Dencker L. Tissue distribution and retention of ${ }^{74} \mathrm{As}-$ dimethylarsenic acid in mice and rats. Arch Environ Cont Toxicol 1984; 13: 25964.

19. Shila S, Subathra M, Devi MA, et al. Arsenic intoxication-induced reduction of glutathione level and of the activity of related enzymes in rat brain regions: Reversal by DL $\alpha$-lipoic acid. Arch Toxicol 2005; 79: 140-46.

20. DeSesso JM, Jacobson CF, Scialli AR, et a]. An assessment of the developmental toxicity of inorganic arsenic. Reprod Toxicol 1998; 12; 385-33.

21. Styblo M, Drobna Z, Jaspers I, et al. The role of biomethylation in toxicity and carcinogenicity of arsenic: A research update. Environ Health Perspect 2002; 110: 767-71. 